\title{
Making Republicanism Useful
}

\author{
Linda K. Kerber†
}

There is not a single more unintelligible word in the English language than republicanism.

-John Adams

The only place where the word "republican" appears in the Constitution is article IV, section 4: "The United States shall guarantee to every state in this union a Republican form of government, and shall protect each of them against invasion; and, on application of the legislature, or of the executive, (when the legislature cannot be convened), against domestic violence." In the conversation of the Constitutional Convention, republicanism was simply what monarchism was not. Madison's definition in Federalist No. 39 was broad: "we may define a republic to be, or at least may bestow that name on, a government which derives all its powers directly or indirectly from the body of the people, and is administered by persons holding their offices during pleasure, for a limited period, or during good behavior." Ample room was left for competing interpretations.

In the last 25 years or so, historians of the founding generation have developed an appreciation for the rich and complex strain of republican ideas which were available in the late eighteenth-century and especially for the Founders' indebtedness to the republican theorists of the Renaissance. Like the classic psychologists' test design of the old woman and the young woman embedded in the same drawing, once historians were taught to see the elements of classical republicanism in the texts of the founding generation it became, for a while, hard to see anything else. The themes of classical republicanism are unsettling. First, they undo the traditional understanding-made familiar in Carl Becker's classic of 1922, The Declaration of Independence-that the central philosophical influence on the Founders was Locke. Lockean emphasis on the protection of individual rights was destabilized as the sole foundation of American constitutional thought; participation in the political community became freshly important. ${ }^{2}$ Second, the themes of classical republicanism position themselves in

\footnotetext{
† May Brodbeck Professor in the Liberal Arts and Professor of History, University of Iowa.

1. The Federalist No. 39, at 243-44 (J. Madison) (E. Earle ed. 1937).

2. Isaac Kramnick has summarized this aspect of republicanism succinctly:

Man was a political being who realized his telos only when living in a vivere civile with other propertied, arms-bearing citizens, in a republic where they ruled and were ruled in turn.
} 
sharp contrast to democracy: In a scheme in which the political world is divided into the One, the Few, and the Many, classical republican thought emphatically favors the propertied Few. This helps explain how the Founders could be comfortable with a political community which excluded the propertyless and why in the republic of 1787 only a minority of adults voted. These undemocratic aspects of 1787 now seem less accidental, more intentional than they once did. Third, classical republican discourse stands in a skeptical relationship to commerce and capitalism. Among the Whig Opposition it had been a language of nostalgia, pitting the Country against the Court, the rural against the commercial. To the extent that Americans of the 1780's and 1790's were republican, it becomes impossible to see them as a rising class of capitalists. Neoprogressive verities, at least as old as Charles Beard's studies of the economic interests of the members of the constitutional convention, are left looking for a solid grounding. In a world constructed by the heirs of civic humanists, Locke - with his vision of political order emerging from a state of nature in which men and women are endowed with rights to life, liberty, and property-begins to look like an innocent abroad. In J.G.A. Pocock's magisterial work on republicanism, the American Revolution becomes the last of a series of British revolutions, an episode in the history of the Renaissance and the early modern era, not the first act in a new Age of Enlightenment. ${ }^{3}$

It is this revisionist understanding of the role and significance of classical republican discourse to which both Sunstein and Michelman have turned in their contributions to this symposium. Both use the phrase "republican revival" and suggest that the readers' task is to develop an opinion about that revival. Sunstein locates himself among "modern republicans"4 and searches for "those aspects of republican thought that have the strongest claim to contemporary support"; he offers to "outline and defend a particular version of republican thought." ${ }^{\prime \prime}$ And both essayists find compelling the same aspects of civic humanism: the emphasis on participation and deliberation in civic life.

Historians are most apt to find disconcerting the claim that we must now take a position on republicanism-that in Sunstein's terms, we must "support" it. Historians are more comfortable thinking of themselves as

Behind this republican discourse is a tradition of political philosophy with roots in Aristotle's Politics, Cicero's Res Publica, Machiavelli, Harrington, Bolingbroke, and the nostalgic country's virtuous opposition to Walpole and the commercialization of English life. The pursuit of public good is privileged over private interests, and freedom means participation in civic life rather than the protection of individual rights from interference.

Kramnick, The "Great National Discussion": The Discourse of Politics in 1787, 45 WM. \& MARY Q. 3, 4-5 (1988). See also Kramnick's apposite footnote to this passage.

3. This point is developed throughout Three BRITISH Revolutions: 1641, 1688, 1776 U.G.A. Pocock ed. 1980).

4. Sunstein, Beyond the Republican Revival, 97 YALE L.J. 1539 (1988).

5. Id. at 1541 (emphasis added). 
engaged in the act of uncovering, of eliciting from the discourse of past societies elements of argumentation which will enable us to understand these societies in all their distance and strangeness.

Both Sunstein and Michelman disarmingly acknowledge that they want to retrieve only some aspects of classical republicanism. The classical republican tradition assumed that deliberation was possible only in small and exclusive communities; the absence of the dependent classes - defined by race, gender, and property - was essential to the republican view of the world, not an easily correctable accident. Emphasis on arms-bearing gave the republican tradition a militaristic core. Emphasis on deliberation did not necessarily guarantee, as Michelman has acknowledged, "an authentic consensus. . . . When everyone is civically virtuous, how is it settled who gives in, if decision is neither by brute voting nor by domination, whether brute or subtle?"' Viewed from this perspective, republicanism brings us uncomfortably close to Rousseau's General Will.

Michelman and Sunstein each seek a discourse which retrieves the civic virtue and the dedication to deliberation and the common good that was one side of republicanism and links them to liberalism's respect for individual privacy and diversity, abandoning at the same time republicanism's tendency to homogeneity and the tyranny of the majority as well as liberalism's tendency to enshrine private property rights. In a community of discourse which has in the last few years been unable to escape from demands for original intent argumentation (even when denying that original intent ought to bind us), ${ }^{7}$ the argumentative strategy displayed in these papers is an intriguing departure. For their part, Sunstein and Michelman turn to the founding generation for a language that offers a historical pedigree ${ }^{8}$ for a freshly dynamic understanding of the potential of American political thought and also provides justification for energetic public policy choices in the present. Can they find there what they seek?

The uses Sunstein and Michelman make of the work of the founding generation are compatible, but distinct; they require separate readings. Both authors counterpose a republican tradition against a "pluralist" one, with pluralism understood to be the unrestrained competition of private interests, the side of liberalism which is traditionally contrasted with its universalist, tolerant side.

Sunstein separates his reflections into two parts, one seeking to locate

6. Michelman, The Supreme Court, 1985 Term-Foreword: Traces of Self-Government, 100 H^Rv. L. REv. 5, 21 (1986). Sunstein concedes this point: "the republican belief in the subordination of private interests to the public good carries a risk of tyranny and even mysticism." Sunstein, supra note 4 , at 1540 .

7. See Powell, The Original Understanding of Original Intent, 98 HARv. L. REv. 885 (1985)

8. Sunstein, supra note 4 , at 1540 . 
the elements of republicanism in the argumentation of the founding generation, and one addressing the implications of republicanism for policy choices in the present. He hedges his bets by offering a "particular version," which he calls "liberal republicanism." This formulation burdens the reader with the responsibility of distinguishing the debt that each of the "central principles" which follow owes to the liberal or the republican side of the Constitution: If "civic virtue" comes from republicanism, "equality" surely derives from liberalism. ${ }^{9}$ This amalgam seriously muddies the argumentative waters; it is all right to end with a synthesis, but to start with one and tease out its elements, only to return to it again, is to invite frustration. ${ }^{10}$

Although he acknowledges that the lines are not precise, Sunstein locates classical republicanism among the Antifederalists. ${ }^{11} \mathrm{He}$ is on reasonably solid ground in doing this; he is thinking of Gordon Wood's argument that the construction of the Constitution marks the end of classical republicanism in America. Nevertheless, his approach should be treated with caution. Indeed, only a few pages later, Sunstein himself acknowledges the persistence of classical republican thought among Federalists, particularly in Madisonian conceptions of representation and in the universal stress on the need for virtue and intelligence among the people as a whole. ${ }^{12}$ The entire revolutionary generation, both Federalists and Antifederalists, were heirs of the classical republican tradition. If there is much in Antifederalist ideology which conveys the republican tradition especially its emphasis on small scale politics and intense citizen participation - there is also a great deal, perhaps even more, in Federalist ideology which also embodies republican tradition, including an intense consciousness of the fragility of republics, of the natural inequality of the social classes, and of the threat to virtue posed by ambition, luxury and lust, i.e., by effeminacy.

In some moods, Sunstein recognizes that congruities work in both direc-

9. Id. at 1541; see also id. at 1567-69.

10. Sunstein's argument is often opaque. For example, he offers "universalism" as a basic characteristic of republicanism, but goes on to define universalism "in a somewhat idiosyncratic sense" as a commitment which "amounts to a belief in the possibility of mediating different approaches to politics, or different conceptions of the pubic good, through discussion and dialogue." Id. at 1554. This is a definition of a characteristic commitment to "deliberation," perhaps; I see nothing in this sentence which enriches our understanding of universalism. Yet Sunstein proceeds with the confidence that a particular characteristic of republicanism has been freshly defined, and embeds this assumption in the rest of the work.

11. Id. at 1556. In his Harvard Law Review essay of 1986, Michelman also treats republican thought as "other." "The role," he writes, "is that of a counter-ideology, a normative political vision to set against the vision believed to have predominated in the thought of the framers and in the Constitution they framed." Michelman, supra note 6, at 17-18, citing G. STONE, L SEIDMaN, C. Sunstein \& M. Tushnet, Constrtutional. Law (1986). Jennifer Nedelsky also draws this sharp distinction, making the antifederalists proponents of deliberative politics based on civic virtue. Nedelsky, Confining Democratic Politics: Antifederalists, Federalists, and the Constitution, $96 \mathrm{HARv}$. L. REV. 340 (1982).

12. Sunstein, supra note 4 , at $1559-61$. 
tions: he quotes the leading Antifederalist Patrick Henry on "self-love" as the "real rock of political salvation"13 and Federalist No. 10 on those elements of Madisonian thought which echo traditional republican belief. $\mathrm{He}$ also recognizes that a unitary focus on the civic good "depends on a denial of difference and a belief in transcendence of context."14 These denials establish a myth of universality and make it difficult if not impossible for disadvantaged groups-disadvantaged by race, sex, gender, poverty-to press their particular "perspectives and interests."15 In republican discourse, everyone is represented personally by themselves or by members-at-large. A reader of Sunstein's essay cannot help but ask what a progressive like himself is doing in republican company, where, as Hanna Pitkin has recently reminded us, it is commonly understood, with Machiavelli, that "Fortune is a woman, and it is necessary to keep her under, to cuff and maul her."16

Frank Michelman also offers a republicanism shorn of its authoritarian aspects. He acknowledges these aspects clearly and with subtlety, locating them in the characteristic myth "of the heroic Founder or Legislator . . . [which] . . . describes an ideal history of the republic in which there was and will be only one act of political-moral originality . . ."17 To make this myth the core of Republican thought is, of course, to believe that American republicanism is exceptional. Even though they have been mythologized as "Founding Fathers," the men at the Constitutional Convention are transparently not mythical, and the amendment provisions of the Constitution are unambivalent about the prospect for continuing acts of political originality. Michelman seeks to cleanse "We the People" of the ironies of classical republicanism (not least of which is the fact, as Stanley $N$. Katz has recently pointed out, that there is no reference to equality in either the Constitution or the Bill of Rights), ${ }^{18}$ defuse it of its antique association with arms and violence, and offer an American republicanism

13. Id. at 1558. Bernard Bailyn has recently offered a reading of Antifederalist argumentation which stresses Antifederalist references to self-interest as the engine that most reliably drives the political machine. Bailyn, The Ideological Fulfillment of the American Revolution: A Comment on the Constitution (unpublished paper, American Historical Association Annual Meeting, Washington, D.C., Dec. 1987). On both Federalists and Antifederalists as inheritors of republican thought, see Murrin, The Great Inversion, or Court versus Country: A Comparison of the Revolution Settlements in England (1688-1721) and America (1776-1816), in THREe BRITISH Revolutions: 1641, 1688,1776 (J.G.A. Pocock ed. 1980). On the centrality of republican ideas among Federalists, see Appleby, The American Heritage: The Heirs and the Disinherited, 74 J. AM. Hist. 798, 801 (1987).

14. Sunstein, supra note 4 , at 1572 .

15. Id.

16. H. Prtkin, Fortune is a Woman: Gender and Politics in the Thought of Niccolo Machiavelli 152 (1984). Sunstein backs off, however, from his criticism of republican pressure toward homogeneity: "[a] belief in universalism need not be accompanied by a desire to erase differences. Indeed, republicans see disagreement as a creative and productive force, highly congenial to and even an indispensable part of the basic republican faith in political dialogue." Sunstein, supra note 4, at 1575.

17. Michelman, Law's Republic, 97 YaLE L.J. 1493, 1515 (1988).

18. Katz, The Strange Birth and Unlikely History of Constitutional Equality, 75 J. AM. HIST. 747 (1988). 
constructed by the Many, not the Few. Instead of Sunstein's "liberal republicanism" Michelman offers "inclusory republicanism." this republicanism not only from classical sources, but also from The Federalist, or, as he prefers to say, "Publius," especially No. 39, where a defense of the government as republican is offered with virtually no reference to its classical republican characteristics. Michelman is interested in American republicanism as an answer to Rousseau's question: How can a person be understood to be controlled and yet free ${ }^{20}$ Michelman is confident that a republicanism can be created free of the features that he does not want it to have.

$* * * * *$

If the language of civic republicanism will help us in the present to strengthen those aspects of the political order committed "to political equality, deliberation, universality and citizenship," more power to the "republican revival." Yet one is left doubting whether the republicanism sought by Sunstein and Michelman-especially Sunstein, whose claims are less cautious-is to be found where they search. Neither essayist recognizes, for example, that classical republican discourse was a language of political nostalgia in the $1790{ }^{\prime} \mathrm{s}^{21}$ Neither essayist has addressed the close connection throughout the early modern period between classical republican thought and the politics of patriarchy; neither has understood liberalism as a critique of patriarchy-Locke wrote, after all, in response to Sir Robert Filmer's Patriarcha. Patriarchy was comfortably compatible with classical republicanism: the head of the family represented the family (and its servants and slaves) in its relationship to the state. A patriarchal family and a democratizing society were discordant; to undermine patriarchy, Americans would have to draw on Locke and on Scottish Common Sense philosophy, with its confidence in the capacity of all humans to claim happiness. "Do not put such unlimited power in the hands of the Husbands," wrote Abigail Adams; "Remember, all Men would be tyrants if they could."23 Slavery, too, was comfortably compatible with classical republicanism, and for many of the same reasons. Where property interests were not deeply threatened by emancipation, liberal republicanism

19. Michelman, supra note 17 , at 1504 n.38.

20. Id. at 1500-01.

21. Cohen, Explaining the Revolution: Ideology and Ethics in Mercy Otis Warren's Historical Theory, 37 WM \& MARY Q. 200 (1980); Cohen, Mercy Otis Warren: The Politics of Language and the Aesthetics of Self, 35 AM. Q. 481 (1983). Lester Cohen's work makes it clear that when women tried to rely on civic humanism to validate their claims on the republic, they found themselves marginalized. On this point, see Bloch, The Gendered Meanings of Virtue in Revolutionary America, 13 Signs 37, 56 (1987).

22. On patriarchy, see Burrows \& Wallace, The American Revolution: The Ideology and Psychology of National Liberation, 6 PERSP. AM. HIST. 167 (1972).

23. Letter from Abigail Adams to John Adams, Mar. 31, 1776, reprinted in 1 ADAMs FamLY Correspondence 369-70 (L. H. Butterfield ed. 1963). 
could sustain critics of slavery, as it did, for example, in the Quock Walker case ${ }^{24}$ and in efforts to enact gradual manumission laws in New York and New Jersey. But in the South neither classical republicanism, with its privileging of patriarchy, nor liberal republicanism, with its privileging of property rights, could be of much help to slavery's critics; they would have to turn to Christian concepts of virtue and the equality of all souls in God's eyes for the foundation of their attack. Among Baptists and Methodists slaves might find a welcome, and Martin and Gabriel Prosser found sustenance for rebellion in their Christian faith as well as in their experiences during the Revolution. ${ }^{25}$

Traditional republican theory could not help either Jeffersonians or Federalists think creatively about the place of women in republican society. The answer to the conundrum of why Americans of the revolutionary generation found it so difficult to think about women in revolutionary terms when the French Left was able to do so lies in part in the extent to which American political discourse was embedded in its republican sources. When Elizabeth Cady Stanton and her colleagues wanted to demand a place in the republican polity, republican discourse helped them little. To sustain the proposition that all are created free, equal, and independent, they needed Locke, not Machiavelli. ${ }^{28}$

Thus patriarchy was embedded in classical republicanism as well as in monarchy. The habit of dominion in the private sphere accustomed male heads of households to responsible political choices in the public sector; the home was "a little commonwealth" in an ironic sense as well as a straightforward one. To call for a "republican revival" in the abstract is to skirt the mutually reinforcing aspects of eighteenth century political culture which sustained republicanism: not only patriarchy in the home, but also the Calvinism that undergirded concepts of Christian virtue and the understanding of gentlemanly honor (as opposed to the mob) that sustained civic virtue-those elements which James Oakes has recently linked to the "profound elitism of classical republicanism."27

Both Sunstein and Michelman have located as quintessentially republican a stress on deliberation and process, on the need to balance self-love by a concern for the public good, on the goal that political decisions also

24. Commonwealth v. Jennison (1783), reprinted in 4 Judicial Cases ConCERning American Slavery and the Negro 480-81 (H.T. Catterall ed. 1936) (Massachusetts Supreme Court of Judicature declared slavery inconsistent with "free and equal" clause of Massachusetts Constitution).

25. On Gabriel's Rebellion, which resulted in the execution of approximately 20 black men in Richmond, Virginia in the fall of 1800 , see G. MUluin, Flight and Rebel.lion: Slave ResisTANCE IN EIgHTEENTH-CENTURY ViRginia 140-63 (1972).

26. I have made this point in another form in Kerber, The Republican Ideology of the Revolutionary Generation, 37 AM. Q. 474, 483, 488 (1985). For a cogent argument, which also makes the Woman Question a test of republicanism's contemporary usefulness, see Hendrik Hartog's vigorous essay, Imposing Constitutional Traditions, 29 WM. \& MARY L. REV. 75 (1987).

27. Oakes, From Republicanism to Liberalism: Ideological Change and the Crisis of the Old South, 37 AM. Q. 569 (1985). 
be ethical ones. But in classical republicanism, the deliberators were the Few, not the Many, and the boundaries of who might participate in that deliberation were carefully and narrowly drawn. Although Sunstein sees a sharp contrast between interest-group politics and deliberative politics, he does not address the likelihood that even after extensive deliberation, the votes may well reflect some form of self-interest after all. Beware the abstract do-gooder. ${ }^{28}$ Against corruption, the Founders were likely to offer their confidence that a society of yeoman farmers, where landed property was widely distributed, could resist temptation. Moreover, while it is true that political discourse in the founding generation was infused with implicit understandings of the locus of deliberation, the understandings were contested. "Theoretically," write W. B. Allen and Gordon Lloyd, "Antifederalists conceived of representation as a device to facilitate the direct expression of the will of the people [and] . . conceived of the deliberation pre-requisite to sound governing as . . . taking place within the body of the people."29 Federalists regarded representation as a device to facilitate deliberation. When the Founders feared corruption, it was not deliberation which they set against it. Nor, indeed, did they normally use the term "deliberation" to suggest a collective activity. The opening sentence of Federalist No. 1 is addressed "To the People of the State of New York," who, facing an election, by universal male suffrage, of delegates to the ratifying convention, "are called upon to deliberate on a new Constitution ...." This deliberation will take place in each individual's own mind, and will influence the outcome of his vote. Hamilton acknowledges that his own mind is made up: "I will not amuse you with an appearance of deliberation, when I have decided." At the very least, the uses of the word deliberation were various, and did not necessarily privilege a certain form of shared discussion in particular contexts like town meetings or legislatures. In the end, Sunstein belatedly acknowledges that

most of the great liberal thinkers . . . [also] placed a high premium on deliberation and discussion, and on the capacity of political dialogue to improve outcomes and to undermine unjustified disparities in power. . . In their emphasis on the possibility of forming public policy through deliberation, on political equality, on citizenship, and on the salutary effects of publicity, republicanism and liberalism are at one. ${ }^{30}$

28. On the reciprocal relationship between participation and authenticity, see Tomkins, The Psychology of Commitment, in The ANTISLAvery Vanguard: New Essays ON THE Abolitionists 270, 279-92 (M. Duberman ed. 1965).

29. The Essential Antifederalist 138 (W. B. Allen \& G. Lloyd eds. 1985). For a thoughtful discussion of deliberation, which ends by counterposing deliberation of a large group to corruption within a small group, see Speech by Melancton Smith, given before the New York Ratifying Convention (June 20,1788), reprinted in id. at 175-76.

30. Sunstein, supra note 4 , at 1567-68. 
What, then, is left of the distinctive characteristics of republicanism to which Sunstein urges us to turn? ${ }^{31}$ Where is the historical pedigree we were promised?

Neither Sunstein nor Michelman makes fine distinctions between the republican rhetoric of community and citizenship and similar rhetoric deriving from Marx and socialist thought. They happily find in republican discourse language which sustains participation and deliberation, but they will not find in it language which supports claims of equal rights of access to the community of participation and deliberation. For this claim they will need liberal and socialist language. Indeed, American traditions of dissent have been sustained by many discourses: the language of Christian separate salvation; the liberal language that turned to the universalism of natural law to sustain arguments for equality, toleration, individual rights and civil liberties; both socialist and commonwealth rhetoric of cooperation and civic virtue; and feminist discourse which insists on the social construction of relationships hitherto understood to be natural..$^{32}$ The work of Sean Wilentz for the North and James Oakes for the South has recently made clear the extent to which, in Oakes' words, "republicanism always functioned as an expression of alienation and opposition."33 Republican language of all varieties has continued to be central to American political discourse, particularly of the dissenting left, as has recently been freshly demonstrated by Sara Evans, Harry Boyte, and James E. Miller. ${ }^{34}$

Republican language has been central to American dissent in large part because it embodies collectivist values while at the same time avoiding the Marxist language of which Americans have long been skeptical. In turning to it now for a vantage point from which they can demand a strict scrutiny for public deliberation, Sunstein and Michelman are themselves in a long and distinguished tradition of American dissent. It is almost impossible to find 1780 's republicanism nuanced precisely as they would wish - participation without exclusion, virtue without elitism. Nor is it possible to find dissenters who really want eighteenth century liberalism back. Like Sunstein and Michelman, American dissenters traditionally

31. In both systems, "a requirement of neutrality or impersonality . . . plays an important role :..."Id. at 1568. Thus Sunstein is brought back to his opening construction of "liberal republicanism"-a construction which, as I have said, fuses the most appealing elements of the two most prominent political languages of the early republic. "Republican thought, understood in a certain way, is a prominent aspect of the liberal tradition." Id. at 1569.

32. Recent essays which emphasize diverse sources for the political thought of the early republic are Kramnick, supra note 2; Bloch, supra note 22; and Kloppenberg, The Virtues of Liberalism: Christianity, Republicanism and Ethics in Early American Political Discourse, 74 J. AM. HIST. 9 (1987).

33. Oakes, supra note 27, at 555; S. Wilentz, Chants Democratic: New York City and THE RISE OF THE AMERICAN WORKING Class, 1788-1850 (1984).

34. S. Evans \& H. Boyte, Free Spaces: The Sources of Democratic Change in America (1986); J. Milleer, Democracy is in the Streets: From Port Huron to the Siege of Chicago (1987). 
want liberalism with their republicanism: a large state with participatory democracy; a neutral state with substantive visions of the public good; minority rights with majority rule.

It may be useful to have these claims made in the rhetoric of the Founders because, in practice, theirs are the voices to which we have been trained to listen. What are the alternatives, after all? To ally oneself with Marxian dissent is to foreclose a hearing by centrist opinion in America; to ally oneself with the Antifederalists is to be caught on the losing side. I remain skeptical of neorepublicanism for its romanticized constructions of the past. It was not the civic humanists to whom women, blacks, Jews, and the marginalized groups of modern times have been able to turn for solutions. At best, and viewed with careful selectivity, neorepublicanism provides a flying buttress to one wall of the structure of liberalism. If we are going to repudiate the side of liberalism that privileges the market and the contract (as the Baby $M$ case has challenged us, most recently and most directly, to do), we need to repudiate it directly and explicitly; neorepublicanism helps, but only a little.

I end with the wish that Sunstein and Michelman acknowledge the historical tradition on which they depend: the continuous presence throughout the history of American dissent of the rhetoric of a commonwealth of cooperation and civic virtue. It is anachronistic and unnecessary to reach back over the last two hundred years to claim the republicanism of the early modern era. Whenever the competitive individualism of bourgeois liberalism has appeared to be the central problem, American dissenters have turned to republican themes. Now, I would agree, is such a time. This resilient republican language fused with major liberal elements has continued to be central to American political discourse, especially of the Left. It has always had a radical potential, and Sunstein's and Michelman's own essays are striking examples of its continuing power. 